\title{
INTRODUCTION TO THE TATE ISSUE
}

\author{
SUSAN FRIEDLANDER
}

Last year the AMS published the Collected Works of John Tate1 whose brilliant mathematics revolutionized areas of number theory, algebraic geometry, and algebra. His scientific accomplishments place him among the most significant mathematicians of the 20th century. This issue of the Bulletin of the American Mathematical Society celebrates John Tate and the publication of his collected works. For over more than six decades, Tate's work has been recognized by many awards and distinctions including the Abel prize in 2010 "for his vast and lasting impact on the theory of numbers and the wealth of essential mathematical ideas and constructions that he initiated". The articles in this issue of the Bulletin illustrate some of these ideas and give a historical overview of Tate's prolific collaboration with Jean Pierre Serre.

The influence of Tate's work was spread not only through his groundbreaking publications but also through his many $\mathrm{PhD}$ students, mainly during his professorship at Harvard from 1954 to 1990 after which he became the Sid W. Richardson Chair in Mathematics at the University of Texas in Austin. These mathematicians are listed in Table 1

\section{TABle 1. List of FORMER STUdente 2}

Edward Assmus, Jr.
Leonard Evens
James Cohn
Andrew Ogg
Stephen Shatz
Jonathan Lubin
Saul Lubkin
Judith Obermayer
Stephen Lichtenbaum
J. Michael Schlessinger
John Labute
Gustave Efroymson
John McCabe
James Milne
Shankar Sen
Robert Warfield, Jr.
George Bergman

$\begin{array}{ll}\text { Harvard University } & 1958 \\ \text { Harvard University } & 1960 \\ \text { Harvard University } & 1961 \\ \text { Harvard University } & 1961 \\ \text { Harvard University } & 1962 \\ \text { Harvard University } & 1963 \\ \text { Harvard University } & 1963 \\ \text { Harvard University } & 1963 \\ \text { Harvard University } & 1964 \\ \text { Harvard University } & 1964 \\ \text { Harvard University } & 1965 \\ \text { Harvard University } & 1967 \\ \text { Harvard University } & 1967 \\ \text { Harvard University } & 1967 \\ \text { Harvard University } & 1967 \\ \text { Harvard University } & 1967 \\ \text { Harvard University } & 1968\end{array}$

\footnotetext{
${ }^{1}$ Collected Works of John Tate, Parts I and II, Barry Mazur and Jean-Pierre Serre, editors, Volume 24, American Mathematical Society, 2016.

${ }^{2}$ This list originally appeared in Collected Works of John Tate, Part I, Barry Mazur and Jean-Pierre Serre, editors, Volume 24, American Mathematical Society, 2016.
} 


\section{TABle 1 (CONTINUED)}

$\begin{array}{lll}\text { William Waterhouse } & \text { Harvard University } & 1968 \\ \text { Michael Razar } & \text { Harvard University } & 1970 \\ \text { Carl Pomerance } & \text { Harvard University } & 1972 \\ \text { Kenneth Kramer } & \text { Harvard University } & 1973 \\ \text { Kenneth Ribet } & \text { Harvard University } & 1973 \\ \text { Lawrence Risman } & \text { Harvard University } & 1973 \\ \text { Alan Candiotti } & \text { Harvard University } & 1974 \\ \text { Joseph Carroll } & \text { Harvard University } & 1974 \\ \text { Joe Buhler } & \text { Harvard University } & 1977 \\ \text { Daniel Flath } & \text { Harvard University } & 1977 \\ \text { Robert Kottwitz } & \text { Harvard University } & 1977 \\ \text { Jerrold Tunnell } & \text { Harvard University } & 1977 \\ \text { James Weisinger } & \text { Harvard University } & 1977 \\ \text { Benedict Gross } & \text { Harvard University } & 1978 \\ \text { Theodore Chinburg } & \text { Harvard University } & 1980 \\ \text { Vijaya Murty } & \text { Harvard University } & 1982 \\ \text { Joseph Silverman } & \text { Harvard University } & 1982 \\ \text { Gregory Call } & \text { Harvard University } & 1986 \\ \text { Jeremy Teitelbaum } & \text { Harvard University } & 1986 \\ \text { Dinesh Thakur } & \text { Harvard University } & 1987 \\ \text { Stephen DiPippo } & \text { Harvard University } & 1990 \\ \text { Ki-Seng Tan } & \text { Harvard University } & 1990 \\ \text { Joongul Lee } & \text { University of Texas at Austin } & 1996 \\ \text { Karrolyne Fogel } & \text { University of Texas at Austin } & 1998\end{array}$

John Tate himself received his $\mathrm{PhD}$ from Princeton University in 1950 with Emil Artin as his thesis advisor. According to the Mathematics Genealogy Project, Tate traces his mathematical lineage through a very famous group whose family tree includes Hölder, Kummer, Bessel, and the great mathematician Carl Friedrick Gauss. With this Germanic ancestry in mind, we chose a postage stamp picturing Gauss as the cover image for the Tate issue of the Bulletin. This stamp was issued by the Deutsche Bundespost in 1955 to commemorate the centennial of Gauss's death.

The material in this issue of the Bulletin is the following.

- John Tate surveys number theory in the 20th century. Here we publish part 1 covering 1900-1940. Part 2 will be published in a future issue of the Bulletin.

- J. S. Milne reviews the Collected Works of John Tate.

- Pierre Colmez presents Tate's work and the Serre-Tate correspondence.

- Burt Totaro writes on recent progress on the Tate Conjecture.

- Joseph Silverman discusses Tate's "Haverford" lecture notes on the arithmetic of elliptic curves.

The final two articles survey recent mathematics whose roots connect with different areas pioneered by John Tate, namely rigid analytic spaces and $K$-Theory. These surveys are

- Herwig Hauser's article on the classical Artin approximation theorems.

- Alexander Merkurjev's article on the essential dimension, introduced by J. Buhler and Z. Reichstein. 
To demonstrate the number and significance of the topics to which John Tate made fundamental contributions, we reproduce on the following pages the table of contents of an article by J. S. Milne on the work of John Tate that appeared in the book series on the Abel Prize winners.

Department of Mathematics, University of Southern California, los Angeles, CalIFORNIA, 90089

E-mail address: susanfri@usc.edu 